\title{
CHALLENGES ENCOUNTERED IN RELIGIOUS EDUCATION IN TURKEY
}

\author{
AYTEKIN DEMIRCIOĞLU \\ Kastamonu University Science and Literature \\ Faculty Philosophy Department, 37150, Kastamonu, Turkey \\ E-mail adress: demircioglu.aytekin@gmail.com \\ ORCID: https://orcid.org/0000-0003-4945-5519
}

\begin{abstract}
Aim. In this study, the challenges encountered during the introduction of religious education in Turkey are examined within the scope of their intended solutions.

Methods. In this study, challenges encountered in the implementation of religious education in Turkey are being discussed in a descriptive manner. Literature scanning and interpretation methods, one of the qualitative research methods, were used in the study.

Results. Religious education in Turkey is both maintained within the formal education system and the non-formal education system. Formal education is provided in public schools run by the Ministry of National Education [MNE]. Primary, secondary and high school education is compulsory for all students. There are Imam Hatip Schools that were opened to provide religious education at secondary and high school level. There are also two hours of compulsory religious education per week in other schools. Non-formal religious education is provided only by the Presidency of Religious Affairs [PRA]. This training is given to people of all ages. For this purpose, the PRA opens several courses.

Conclusions. In this study, challenges encountered related to religious education in Turkey are being discussed in two main areas: Challenges in formal education are examined under seven subtitles. Challenges in non-formal education are examined under eight subtitles.

Originality. This study is an original study in terms of addressing the challenges in formal and non-formal religious education together. In addition, the possibility of making a collective examination of challenges related to religious education in Turkey would be valuable to the reader.

Key words: education, religious education, education in Turkey, religious education in Turkey, religious education challenges
\end{abstract}

\section{INRODUCTION}

Dducation is the process of bringing permanent changes in one's life. This Eprocess should be carried out at one's own request. The change of beha-

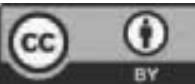


viour that occurs at the end of the process should be positive and observable by others.

According to another definition, education is the task of regularly transferring or gaining knowledge and experiments of the past within every generation (Science and Art Terms Dictionary [SATD], 1974).

Religious education, can be defined as the process of guiding individuals to develop their religious feelings, thoughts and attitudes by using their own religious experiences (Asik Ev, 2018). Therefore religious education is a sub-branch or process of general education. For this reason, countries tend to organise religious education within general education systems.

In Turkey, the educational system is divided to formal and informal. Informal education does not have a specific purpose and program and occurs spontaneously in life. Formal education, on the other hand, is the planned and controlled training within the scope of pre-determined goals and programmes. Formal education is divided into two subgroups. The first is organised education: regular and hierarchical education given to individuals of a certain age group at school. The second is non-formal (non-organised) education which is given to individuals of all age groups outside the school and in a non-hierarchical structure (Fidan, 2012).

Religious education in Turkey finds it's place, both within the formal education model and non-formal education model. Formal education starts from kindergarten to university education. In Turkish primary, middle and high schools, formal education is mandatory in each of these sections. In this context, there is twelve years of compulsory education within the scope of formal education. Starting from the fourth grade of primary school until the last grade of high school, two hours of religious lessons per week are compulsory. In addition, there are elective religion classes. Also, there are Imam - Hatip schools that provide religious-intensive education at secondary and high school levels. Some state institutions can operate non-formal education courses. However, religious education courses can only be operated by the PRA. Courses providing religious education in schools done by private institutions are prohibited in Turkey.

In this study, given in the schools connected to the MNE in Turkey, religious education, religious education courses are operated by the PRA of the issues related to religious education were discussed.

\section{METHOD}

Qualitative research design was used in this study. Books that written by specialists and articles on religious education in Turkey were examined during this study. In this regard it has been achieved through document analysis over the challenges encountered in the field of religious education in Turkey. While interpreting the findings obtained in the study, the author's more than twenty years of experience in educational environments were also included. 


\section{HISTORICAL BACKGROUND OF RELIGIOUS EDUCATION IN TURKEY}

There was no standard in education in the Ottoman Empire. Students first went to schools providing basic education at their neighbourhood or village. Then they went to various scholars and took one-to-one lessons from them. The talented students later went to madrasahs and received higher education level there. The madrasah education was of a purely religious character. Schools providing secular education have been opened at the end of the $18^{\text {th }}$ century. Thus, madrasahs providing religious education and schools providing education in the field of positive sciences were separated (Akyuz, 2018).

With the collapse of the Ottoman Empire after the First World War (WWI) on October 29, 1923 the new Republic of Turkey was founded. The new Republic of Turkey, did not identify itself as a religious state in contrast to the Ottoman Empire. Therefore, it adopted a secular system in education. This situation is also reflected in the practices in the field of religious education.

On March 3, 1924; The Republic of Turkey diversed educational institutions of the Union law by removing the state monopoly in education. Based on this law, schools and madrasahs providing religious education were closed. Thus there were no longer tertiary-level religious schools in Turkey. This period continued until the first faculty of theology was opened in 1949. At Ankara University (Yilmaz, 2005). Over time, the number of theology faculties increased and Imam - Hatip Schools were established, providing religious education at secondary school - high school level (Asikoglu, 2017; Dogan \& Capcioglu, 2017; Yuruk, 2017; Zengin, 2011).

Religious education in Turkey is always influenced by the political attitudes of the rulers of the country. For this reason, its place in general education has expanded and sometimes became more narrow. In this study, current challenges in religious education are examined.

\section{CHALLENGES IN RELIGIOUS EDUCATION IN THE SCOPE OF FORMAL EDUCATION IN TURKEY}

\section{Challenges with Teaching Alevi Issues}

Alevism can be briefly defined as "being dependent on Ali" (Actual Turkish Dictionary [ATD], 2020). Ali is the son-in-law and son of his uncle, the prophet of Islam. When Mohammed died, Ali was interested in his funeral, while other Muslims gathered elsewhere and chose the caliph. In this meeting where Ali was not present, Abu Bakr was elected as the new leader of the Muslims. Alevis distinguished themselves from Sunni Muslims, claiming that this meeting was not held correctly and that caliphate was the right of Ali.

Alevism was born in the Arab society and its appearance in the Arab society is militant. It has become a national identity with the Iranian adoption of Alevism. However, Turkish Alevism is more humanistic and far from that (Zelyut, 1991). 
There are three general views on the relationship between Alevism and Islam (Turan, 2018):

- Alevism is a different cultural interpretation within Islam.

- Alevism is a separate belief system completely independent of Islamic belief.

- It changes according to the point of view whether Alevism is inside or outside of Islam.

As it is understood, the subject of Alevism contains various discussions. It can be said that the Turkish state does not have a standard policy in this regard, but that governments carry out different policies periodically. For this reason, the way Alevism takes place in religious classes in schools has varied from time to time.

In a study conducted with Alevi participants (Ozdemir \& Arici, 2011), it was found that Alevis did not have a homogeneous view about the religious lessons given in schools. In this study, 53.8\% of the participants supported the compulsory religion lesson which included Alevi subjects. 81.3\% of the participants stated that religious classes should include Alevi issues. Although there is no consensus among them, $71.5 \%$ of the participants stated that children should learn religious information at school.

Alevis basically demand that Alevism subjects be included in the curriculum of religion. Although these demands have been partially fulfilled in recent years, it is difficult to say that the expectations of the Alevis have been fully met (Kaya, 2018; Subasi, 2011).

The following notions are considered: whether the subjects of Alevism will take place in religion classes in formal education institutions or will it be a detached course; the content of this course; the challenges such as how many hours a week and by whom this course will be taught.

\section{Religious Culture and Moral Knowledge Course Curriculum Related Challenges}

In the Ottoman Empire until the 19th century, there were no training programs for the courses given in madrasahs. Madrasahs were already schools of religious quality (Zengin, 2011).

In the Republic of Turkey, with the establishment of formal education at schools Religious Culture and Moral Knowledge had to be put on the agenda of the course. More than ten teaching programs have been carried out regarding this course since 1924 (Zengin, 2017).

The multiplicity of these programs show that there is no consensus on the content of the religious lessons taught in schools and the number of weekly hours. In addition, the fact that so many religious lesson curricula show that political governments interfere in this area. Therefore, the main problem with the curriculum of religious lessons is that a standardisation in this field cannot be achieved.

While preparing the religious education curriculum, discussions take place on the aims and contents created on the basis of constructivist approach (Altas, 
2011). Similarly, it is stated that while preparing religious education curriculum it should respect the people, different thoughts, freedoms, morals and cultural heritage (Bulut, 2011).

Challenges with Religious Culture and Moral Knowledge Course Books

There are various discussions on how to create the content of the books used in the Religious Culture and Moral Knowledge Course, which topics will be covered at what grade level, and finally the suitability of these books for students' ages.

In a study (Gozutok \& Yilmaz, 2011), only 55.5\% of the students said that the textbooks are of good quality. In this study, $73 \%$ of the students have stated that they needed the textbook while the religion course was being conducted. Those who like the cover design of the textbooks are $41.1 \%$. The rate of those who say "there is no word I do not know / I know all words in the book" in the textbook is $9.7 \%$. It is noteworthy that this rate is quite low.

In a study on religious textbooks conducted with teachers (Keskiner, 2011), it has been stated that the language of religion used in the books was heavy, freedom of religion and conscience was not preserved and the examples were insufficient and subjects were not motivating.

Discussions about the Compulsory Religious Culture and Moral Knowledge Course

From the 4th class of elementary school to the last class of high schools religion lessons in Turkey are taught compulsorily for two hours a week. Currently there is no discussion on this issue. However, from the establishment (1923) of the new state until the 2000s, the necessity of compulsory religion lessons in schools was discussed from time to time.

According to the Constitution of the Republic of Turkey is a secular state. Thus, there is some controversy over whether a secular state should have compulsory religion classes. On the other hand, there are opinions that religious education should be under the control of the state in order to prevent abuse of religion (Uyanik, 2011). Again, some people argue that religion courses in schools should be optional by referring to the decisions of the European Court of Human Rights (Arslan, 2011). In this discussion, there are also opinions that, besides compulsory religion classes, the introduction of elective religion classes for different faith groups is a constitutional right (Yildiz, 2011). There are also opinions that Islamists want compulsory religion lessons rather than moderate Muslims (Pak, 2010). Similarly, there are claims that compulsory religious education restricts the right of the family to choose religious education related to their child (Akbulut \& Usal, 2008).

There is no standard practice and solution worldwide for what the status of religious classes should be in formal education. Some countries have made the religion course compulsory and some elective. In some countries there are both compulsory and elective religion classes. The fact that there are different views on religious education is not only due to the idea of freedom but also the 
political and cultural characteristics of societies (Cebeci, 2011). This problem is not easy to resolve since it has many components.

Challenges Related to the Competence of Religious Culture and Moral Education Teachers

In Turkey since 2012, Religious Culture and Moral Education Department of the Faculty of Education has been linked to the Faculty of Theology. Then, these departments were made passive and they stopped accepting students. Currently, students of the Faculty of Theology Moral can work as Religious Culture and Knowledge Lesson Teachers upon graduation, provided that they take certain courses.

In this case, the students of the Faculty of Theology do not perceive the courses related to education as the courses related to their main fields hence they do not give necessary importance to the courses related to their main fields. Therefore, they graduate without fully acquiring the teaching qualifications. This is the main source of teacher shortages.

The graduates of the Faculty of Theology can work as teachers affiliated to the MNE as well as religious officials affiliated to the PRA. In other words, theology faculty students do not know if they will become teachers or religious officials when they graduate during their studentship. This state of uncertainty is another factor that makes it difficult for students to adopt teaching as a primary profession.

\section{Challenges With Religious Education In Imam - Hatip Schools}

Imam - Hatip schools are formal educational institutions that provide secondary and high school education. The main purpose of these schools is to train religious officials. In these schools, courses on Islamic religion are taught predominantly. Graduates of these high schools mostly go to the faculties of theology. In addition, imam - hatip high school graduates have the opportunity to work as imams (head of mosque) and muezzins (co-imam) in mosques.

It could be said that until the 2000s Political powers in Turkey had approached religious education in a repressive and restrictive style. With the disappearance of this pressurized environment in the last two decades, the number of imam - hatip schools providing religious education has increased rapidly. This rapid increase brought quality challenges with it. Teachers could not be trained in accordance with the schools' increase rate. Imam - Hatip schools could not fully explain their educational functions and purposes to the society (Acuner, 2018; Ayhan, 2014).

There is an entrance exam to high school in Turkey. There are three alternatives for students who cannot pass this exam, that is, cannot go to the high school they want. These students must either go to open high schools that provide distanced education, vocational high schools or imam - hatip high schools. This situation turns imam - hatip high schools into schools filled with students who cannot pass entrance exams to high schools which is an important factor that reduces the quality of these schools. 


\section{Challenges with Religious Education in Higher Education}

Religious education at the tertiary level in Turkey is made in theology and Islamic Studies faculty. As of 2020, there are 68 theology faculties in Turkey and there are 29 Islamic sciences faculties. Although the names of the faculties are different, their functions are the same. The average number of students taken by these faculties each year is 15,000 (Higher Education Council [HEC], 2020).

There are various challenges in the context of the aims of the faculties of theology. Graduates of these faculties can work both in the MNE and in the PRA (Naziroglu, 2018). Employees within the MNE can work as Religious Culture and Moral Knowledge Lesson Teachers in primary and secondary schools and high schools, and as teachers of vocational lessons in imam-hatip secondary and high schools. Thus, graduates of theology can be appointed as teachers in five different groups in the MNE. Similarly, they can Works as imam and muezzin, specialist, religious officials, preachers and mufti. Those who graduate from the faculty of theology receive the same education, although they can work in such separate positions. Students do not specialise in any profession during their faculty education. This is one of the most important challenges of the faculties of theology.

The fact that some of the faculties of religious education at the higher education level are the faculties of theology and some are faculties of Islamic sciences is an indicator of the difference in perception in this field. While faculties of theology are perceived as educational institutions in a more Western style, faculties of Islamic sciences are perceived in a more traditional style (Naziroglu, 2018).

Theology faculties, like other educational institutions in the country, are influenced by the point of view of political powers. Therefore, an autonomy problem related to these faculties can be mentioned.

Especially the negative viewpoints of political governments that existed until 2000's have also created a sociological legitimacy problem in terms of theology faculties (Ayhan, 2014).

In the last two decades, many theology faculties were opened before the necessary preparations were fully made. This brought the quality problem with it.

Another problem in this area is distanced religious education. This training, which was initially considered as an alternative for those who could not continue formal education for various reasons, has caused serious quality challenges after a while (Altas, 2018).

\section{CHALLENGES IN RELIGIOUS EDUCATION IN THE SCOPE OF NON-FORMAL EDUCATION IN TURKEY}

\section{Challenges Related to Religious Education in Mosques}

Since the earliest periods of Islam, mosques have become places of education, as well as places of worship. In addition to the masjid he founded after his immigration to Madinah, Hz. Muhammed also built a training center called suffa (Yilmaz, 2017). 
There are two basic elements of mosque education. The first is the sermon. Sermon is a part of worship during Friday and Eid prayers. The speeches of the imam of the mosque before or after any prayer in order to inform the mosques about religious issues are called sermon or preaching. The preaching is not a part of prayer worship and it is not compulsory to listen to. The other one is khutbah. Listening to the khutbah is mandatory and constitutes a requirement of worship (Dam, 2018).

Apart from these, if ten people request from the mosque community, the imam of the mosque is obliged to open a course for them. These courses provide information on how to read the Qur'an or how to do the prayers properly (Yilmaz, 2017).

The main problem with religious education in mosques is related to the qualifications of the mosque officials who provide this education. There are many challenges such as the mosque staff not being willing enough to give education, lack of knowledge about the area, low general culture level, lack of sufficient interaction with the audience they teach and the lack of teaching skills (Dam, 2018; Yilmaz, 2017).

\section{Issues With Religious Education Given In The Qur'an Courses}

Qur'an courses are non-formal education institutions opened for Qur'an education. There are several types of Qur'an courses (Algur, 2020; Demir, 2018):

- Needs-oriented Qur'an courses: These are courses that usually filter between October and May to people of different age groups. In these courses, basic religious knowledge is taught besides teaching the Qur'an.

- Qur'an courses providing memory education: Hafizlik is the memorisation of the Qur' an completely. This training takes two years on average.

- 4- 6 age group Qur' an courses: These are the courses in which preschool and universal values are taught in addition to reading the Qur'an to preschool children.

- Summer Quran courses: These are the courses that open for students in the summer months when schools are on holiday. Since these courses are short-term, the main purpose of these courses is to provide basic Qur'an reading skills and basic religious knowledge.

The challenges encountered in religious education given in the Qur'an courses can be summarised as follows (Algur, 2020; Korkmaz, 2017):

Since these courses mentioned above are opened in a large number throughout the country, there is not enough qualified and suitable place for education. For this reason, some of the courses are opened in the mosque and some in unsuitable places belonging to local administrations.

There are various challenges about paying the tutors working in these courses. Accordingly, there are not enough tutorials.

There is not much scientific research about the courses of the Summer Quran. Lack of grading system in these courses affects students' perceptions of the course negatively. Courses do not have sufficient educational tools. There 
are challenges concerning motivation and professional competencies of the course staff.

Challenges with the Qualifications of Public Religious Education Officers

Studies show that religious officials have problems in transferring their theoretical knowledge to practice. As a result, they have communication challenges with the mass they serve (Buyrukcu, 2006).

Religious education provides a wide range of services. People with religious education can work at mosques, schools, hospitals, prisons, nursing homes. On the other hand, the education they receive is uniform and is not compatible with a variety of service areas.

The institution organising the common religious education in Turkey is the PRA. However, it cannot be said that the presidency has very clear standards in non-formal religious education. The courses, which are often opened within the scope of widespread religious education, are left to the mercy of the trainers assigned there. Therefore, the quality of the training in these courses is determined by the personal qualifications of the trainers.

The trainers assigned in the courses opened within the scope of non-formal religious education are not all staffed. Personal rights and wages of non-staffed trainers are very low which reduces their productivity.

Religious officials generally do not perceive working in courses as their first job because they are dealing with another job (for example, praying in mosques). This reduces the quality of education in the courses.

\section{Challenges Arising from Sectarian Differences}

The vast majority of the people in Turkey are Muslims. Official authorities accept five denominations of Islam as valid. These sects are Hanafism, Shafism, Hanbalism, Malikism and Caferism, a soft arm of Shiite. Therefore, the textbooks used in religious classes contain information about these sects.

In the textbooks used in religious lessons, there is only introductory information about other branches of Shia, other religions such as Christianity, Judaism, Hinduism and Buddhism. There is no content in textbooks that aims to educate people belonging to these sects or religions from a religious perspective.

Issues with Religious Activities in the Media

The whole world is now in a digital age. In the 1990s, the impact of television on people was discussed. Today, the Internet has become an effective and intensive data providing tool in all areas, including religious education. As of January 2020, 74\% of the population in Turkey (62.07 million) of Internet users; $64 \%$ (54 million) are active social media users; $92 \%$ (77.39 million) have a mobile Internet connection (Kemp, 2020).

It can be said that there are two main opinions regarding the role of media in religious education (Yorulmaz, 2018). According to the first of these, the media is a powerful communication tool and can be turned into a good religious education tool with appropriate content. According to the other view, the media tends to make their content fun to increase viewership rates. This 
does not correspond to religious education, which requires spiritual concentration. In other words, people can watch TV while doing sports or snacking. Religious education cannot be mentioned in such an environment.

There are often sexual and violent publications on TV and the Internet (social media, videos, games). These prevent the achievements targeted with religious education. At the same time, false information is often given during religious education in the media for the sake of gaining more ratings while the content of religion is neglected by discussions on absurd issues that do not benefit people in practice and religion is put into the service of the media. This, rather than informing people about religious issues, blunts their existing knowledge and confuses people's minds in terms of religion. These programs and content, which are mostly prepared without supervision in the name of religious education, often harm religion for the sake of rating.

Challenges With Religious Education In The Family

The family is the first social environment in which the child begins to be involved in society. It is also the place where the child receives their first education in many subjects. Therefore, the family has an important place in the context of religious education. The Islamic prophet said the following in order to emphasise the function that the family attaches to religious education: "Every child is born as a Muslim. Then his parents make him Jewish, Christian or Zoroastrian "(Bukhari, Cenaiz: 79, 80, 93; Muslim, Destiny: 22-25 quoted by Hökelekli, 1996).

The biggest problem in the family in the context of religious education is that parents do not have enough information about this issue. For this reason, parents sometimes cannot answer their children's religious questions, and sometimes they give false or incomplete answers.

\section{Challenges Related to Religious Education Given in Social Service Institutions \\ PRA conducts religious social services in three groups (Ozdemir, 2017):}

1. Family Guidance Offices: These offices were established in order to protect the family structure and answer the religious questions of families. In these offices, various meetings and conferences are organised for families and women.

2. Children's Houses / Orphaneges: Children who remain under the protection of the state remain in these institutions due to various challenges. On certain days of the week, religious officials come here to provide religious education to children.

3. Nursing Homes: They are institutions where the elderly or people in need stay. Religious officials come to these institutions at certain times and provide information on various religious issues.

The common problem encountered in all three of these institutions in the context of religious education is that the personnel assigned in these institutions does not have any special training in this regard. As mentioned earlier, there is no specialisation program in the faculties of theology related to the service areas 
of non-formal religious education. Therefore, a graduate of a theology faculty who started working within the PRA can be appointed in any of these institutions. These people operate in this field, where their education is not received, and they learn the information required by their work during the application.

This situation brings with it many challenges. For example, officials who do not know developmental psychology can attempt to give religious education to children without considering their developmental characteristics.

\section{Challenges Related to Religious Education in Prisons}

Religious education in prisons is carried out according to the protocol between the Ministry of Justice and the PRA in 2011 (General Directorate of Religious Services [GDRS], 2011). According to this protocol, religious staff will be employed in prisons of the PRA. The Ministry of Justice will also make arrangements in prisons for the training of prisoners, provide necessary tools and equipment, and make arrangements to facilitate prisoners' participation.

However, various challenges are encountered in practice. These challenges can be summarized as follows (Ozdemir, 2017):

- Classrooms are not created for education due to lack of place or security in some prisons, and classes have to be held in prisoners' wards. These lessons are inefficient;

- There are not enough religious officials in prisons. There is one educator for an average of 150-200 prisoners;

- Religious officials do not want to work in prisons for reasons such as security concerns or low wages;

- Some prison governors do not attach enough importance to religious education.

\section{RESULTS AND SUGGESTIONS}

There are many challenges with education in Turkey. Crowded classes, disruptions in girls' education, lack of resources are some of them. In some studies, it is suggested that increasing the number of private schools will partially solve these challenges (Cinoglu, 2006). In contrast, the prohibition of opening private religious schools in Turkey, due to the determination of the content as a center of religious classes and programs are not available for the solution of challenges encountered in proposed religious education.

This study describes the challenges encountered during the making of religious education field in Turkey. The following findings from the study:

\section{These suggestions can be listed as follows:}

- More time should be devoted to Alevism issues within religious classes;

- Separate courses about Alevism should be taught at schools electively;

- Religious officials working in places where Alevism is intense should have more accurate information about Alevism; 
- Religious officials should be more tolerant of Alevis and not impose sunnah on them as a belief system;

- Alevi opinion leaders can be used as trainers while teaching Alevi issues;

- Political governments should not interfere with the preparation of religious curriculum;

- Religious education programs should be prepared in the light of scientific developments in the field of education;

- Different belief and thought systems should be included more in religious education curricula;

- Religious textbooks should be prepared in the light of scientific data, dismissing superstitions;

- The physical features and designs of the religious textbooks should be appropriate for the age of the students and be interesting;

- In religious textbooks, abstract topics that are academically controversial and not suitable for students' levels should not be included;

- The narration style should be increased with stories and case studies in religious textbooks;

- Adding dictionaries and concept maps to the end of religious textbooks will increase the utilisation rate of the book;

- Compulsory religious education should be left to the family's preference in schools up to university;

- Elective religion classes should be offered for different faith groups;

- Religious Culture and Moral Education Teaching Departments should be reopened;

- The education period of the faculties of theology should be increased to five years and the last two years should be devoted to professional specialisation;

- Commissions should be created to address the quality challenges in Imam-Hatip schools;

- Student quotas of imam - hatip schools should be determined by considering the number of teachers;

- As a radical suggestion to improve student quality, high school education should be excluded from education and this education should only be offered in a better quality for students who are really willing to take this education;

- The division of theology faculty and faculty of Islamic sciences should be eliminated, and these faculties should not be allowed to group;

- Theology faculties should stop accepting students with very low scores.

- Training programs for faculty of theology should be accelerated;

- In the faculties of theology, specialisation programs should be implemented for students in their last years;

- In order to obtain efficiency from religious education in mosques, mosque officials should be trained and motivated to provide education in every respect;

- The number of practical courses should be increased in Imam - Hatip high schools and theology faculties; 
- In-service training given to current religious officials should be increased. In this training, specialists in the fields of religious education, religious psychology, sociology of religion, and communication should be appointed;

- The fees of the trainers assigned in the courses within the scope of non-formal religious education activities should be improved;

- Religious education textbooks and materials for different religions and sects should be prepared;

- Religious education programs in the media should be prepared and supervised by experts. Broadcasts containing sexual and violent content in the media should be better controlled;

- Parents should be able to provide correct and appropriate answers to their children's questions about religion. The family should get help from the experts if necessary, or state that he / she will "research and respond to this issue" by acting honestly with the child about the things he does not know;

- Religious education personnel assigned in the fields of social work should be trained accordingly in faculties of theology. They must also be subjected to in-service training after graduation;

- The necessary physical infrastructure, classrooms, equipment and equipment deficiencies in prisons should be eliminated;

- Necessary in-service training should be provided to the staff assigned in prisons so that they can communicate well with prisoners.

The conditions of religious officials working in prisons should be improved.

\section{REFERENCES}

[1] Acuner, H. Y. (2018). İmam - hatip okullarında din eğitimi ve sorunlar1 [Religious education and problems in imam - hatip schools]. Ed. Mustafa Koylu. Türkiye'de din eğitimi ve sorunları (içinde) [In: Religious education and problems in Turkey]. 131- 168. Istanbul: DEM Publishing.

[2] Akbulut, O. \& Usal, Z. O. (2008). Parental religious rights vs. compulsory religious education in Turkey. International Journal on Minority and Group Rights, 15(4), 433- 455. Retrieved April 16, 2020 from https://brill.com/view/journals/ijgr/15/4/article- p433_1. $\mathrm{xml}$ ?body $=$ contentSummary-29627.

[3] Akyuz, Y. (2018). Türk eğitim tarihi (32. Basım) [Turkish educational history (32nd Edition)]. Ankara: Pegem Akademi Publishing.

[4] Altas, N. (2018). Yüksek din öğretiminde uzaktan eğitim uygulamaları: ilitam ve sorunları [Distance education applications in higher religious education: ILITAM and problems.]. Ed. Mustafa Koylu. Türkiye'de din eğitimi ve sorunları (içinde) [In: Religious education and problems in Turkey]. 209-238. Istanbul: DEM Publishing.

[5] Algur, H. (2020). Cami ve Kur'an kurslarında din eğitimi [religious education in mosque and Qur'an courses]. Eds. İbrahim Turan \& Bayramali Naziroglu. Din eğitimi (içinde) [In: Religious Education]. 167-184. Ankara: Bilay Publishing.

[6] Altas, N. (2011). Din kültürü ve ahlak bilgisi programlarının amaç - içerik ilișkisi açısından değerlendirilmesi [Evaluation of religious culture and moral knowledge programs in terms of purpose-content relationship]. Eds. Recep Kaymakcan, Mahmut Zengin ve Z. Seyma Arslan. Türkiye'de okullarda din öğretimi (içinde) [In: Religious education in schools in turkey]. 401-410. Istanbul: DEM Publishing.

[7] Arslan, Z. S. (2011). Okullarda isteğe bağlı din eğitiminin imkânı üzerine teorik bir tartışma [A theoretical discussion on the possibility of optional religious education in 
schools]. Eds. Recep Kaymakcan, Mahmut Zengin ve Z. Seyma Arslan. Türkiye'de okullarda din ögrretimi (içinde) [In: Religious education in schools in Turkey]. 129- 152. Istanbul: DEM Publishing.

[8] Asık Ev, H. (2018). Kavramsal çerçeve [Conceptual framework]. Ed. Hasan Dam. Din eğitimi (içinde) [In: Religious education]. 11-31. Istanbul: Lisans Publishing.

[9] Asıkoglu, N. Y. (2017). Yüksek öğretimde din eğitim ve öğretimi (5. Basım) [Religious education and teaching in higher education (5th Edition)]. Eds. Recai Dogan \& Remziye Ege. Din eğitimi el kitabı (içinde) [In: Religious education handbook]. 177-192. Ankara: Grafiker Publishing.

[10] Ayhan, H. (2014). Türkiye'de din eğitimi (3. Basım) [Religious education in Turkey (3rd Edition)]. Istanbul: DEM Publishing.

[11] Bilim ve sanat terimleri sözlüğü [Science and art terms dictionary] (1974). "Eğitim” [“Education”] Retrieved April 15, 2020 from https://sozluk.gov.tr/.

[12] Bulut, Z. (2011). Yeni ortaöğretim din kültürü ve ahlak bilgisi dersi öğretim programının kuramsal temelleri ve inanç öğrenme alanının değerlendirilmesi [Theoretical foundations of new secondary religious culture and moral education curriculum and evaluation of belief learning area]. Eds. Recep Kaymakcan, Mahmut Zengin ve Z. Seyma Arslan. Türkiye'de okullarda din öğretimi (içinde) [In: Religious education in schools in Turkey]. 175-199. Istanbul: DEM Publishing.

[13] Buyrukcu, R. (2006). Türkiye'de din görevlisi yetiştirme problemi ve çözüm önerileri [Chaplaincy education problems in turkey and solutions]. Ankara Üniversitesi İlahiyat Fakültesi Dergisi-AUIFD[Ankara University Faculty of Theology Journal-AUFT]], 47 (2), 99-126. Retrieved April 18, 2020 from https://dergipark.org.tr/en/download/article-file/582982.

[14] Cebeci, S. (2011). İnsan hakları ve inanç özgürlüğü bağlamında din öğretiminin statüsü ne olmalı? [What should be the status of religious education in the context of human rights and freedom of belief?] Eds. Recep Kaymakcan, Mahmut Zengin ve Z. Seyma Arslan. Türkiye'de okullarda din öğretimi (içinde) [In: Religious education in schools in Turkey]. 353-362. Istanbul: DEM Publishing.

[15] Cinoglu, M. (2006). Private education as a policy tool in Turkey. International Education Journal, 7(5), 676-687. Retrieved April 16, 2020 from https:// webapps.flinders.edu.au/education/iej/ articles/mainframe.html.

[16] Dam, H. (2018). Camilerde din eğitimi ve sorunları [Religious education and problems in mosques]. Ed. Mustafa Koylu. Türkiye'de din eğitimi ve sorunları (içinde) [In: Religious education and problems in Turkey]. 131-168. Istanbul: DEM Publishing.

[17] Demir, O. (2018). Kur'an kurslarında din eğitimi [Religious education in Qur'anic courses]. Ed. Hasan Dam. Din eğitimi (içinde) [In: Religious education]. 213-236. Istanbul: Lisans Publishing.

[18] Din hizmetleri genel müdürlüğ ̈ü [DHGM] [General directorate of religious services - GDRS] (2011). Adalet Bakanlığ1 ile Diyanet İşleri Başkanlığı arasında tutuklu ve hükümlülerin dini ve ahlaki gelişimlerini sağlamaya yönelik protokol [Protocol between the Ministry of Justice and the Presidency of Religious Affairs to ensure religious and moral development of detainees and convicts]. Retrieved April 19, 2020 from https://www2.diyanet.gov.tr/ DinHizmetleriGenelMudurlugu/SosyalKulturelIsbirligiPr otokolleri/Adalet\%20Bakan$1 \%$ C4\%B1\%C4\%9F\%C4\%B1\%20Protokol\%C3\%BC.pdf.

[19] Dogan, R. \& Capcioglu, F. (2017). İmam - hatip liseleri (5. Basım) [Imam - hatip high schools (5th Edition)]. Eds. Recai Dogan \& Remziye Ege. Din Eğitimi El Kitabı (içinde) [In: Religious education handbook]. 275-318. Ankara: Grafiker Publishing.

[20] Fidan, N. (2012). Okulda öğrenme ve öğretme (3. Basım) [Learning and teaching at school (3rd Edition)]. Ankara: Pegem Akademi Publishing.

[21] Gozutok, S. \& Yilmaz, N. (2011). İlköğretim II. kademe öğrencilerinin din kültürü ve ahlak bilgisi ders kitapları hakkında görüşleri ile ilgili bir araștırma: Van örneği. [A research about the primary education second level students' views about religious culture and moral knowledge textbooks: the case of Van] Eds. Recep Kaymakcan, Mahmut Zengin ve Z. Seyma Arslan. Türkiye'de okullarda din öğretimi (içinde) [In: Religious education in schools in Turkey]. 429-453. Istanbul: DEM Publishing.

[22] Güncel Türkçe sözlük [Current Turkish dictionary] (2020). "Alevilik" [Alevism]. Retrieved April 15, 2020 from https://sozluk.gov.tr/. 
[23] Hokelekli, H. (1996). Fitrat [Creation]. Türkiye Diyanet Vakfi [TDV] İslam ansiklopedisi [Religious Foundation of Turkey (RFT) encyclopedia of Islam], Vol.13, (pp.47-48). Retrieved April 19, 2020 from https://islamansiklopedisi.org.tr/fitrat.

[24] Kaya, F. (2018). Din Kültürü ve ahlak bilgisi derslerinde Aleviliğin öğretimi ve sorunları [Teaching and problems of Alevism in religious culture and moral knowledge lessons]. Ed. Mustafa Koylu. Türkiye'de din eğitimi ve sorunları (içinde) [In: Religious education and problems in Turkey]. 83-130. Istanbul: DEM Publishing.

[25] Kemp, S. (2020). Datareportal digital 2020: Turkey. Retrieved April 19, 2020 from https:/ / datareportal.com/reports/digital-2020-turkey?rq=Turkey.

[26] Keskiner, E. (2011). Öğretim materyali olarak ilköğretim din kültürü ve ahlak bilgisi ders kitaplarına dair bir araştırma [A research on primary education religious culture and moral knowledge textbooks as instructional materials]. Eds. Recep Kaymakcan, Mahmut Zengin ve Z. Seyma Arslan. Türkiye'de Okullarda din öğretimi (içinde) [In: Religious education in schools in Turkey]. 455-467. Istanbul: DEM Publishing.

[27] Korkmaz, M. (2017): Kur' an kurslarında din eğitimi (5. Basım) [Religious education in Qur'anic courses (5th Edition)]. Eds. Recai Dogan \& Remziye Ege. Din eğitimi el kitabı (içinde) [In: Religious education handbook]. 324-352 Ankara: Grafiker Publishing.

[28] Naziroglu, B. (2018). İlahiyat fakültelerinde din eğitimi ve sorunları [Religious education and problems in faculty of theology]. Ed. Mustafa Koylu. Türkiye'de din eğitimi ve sorunlan (içinde) [In: Religious education and problems in Turkey]. 169- 208. Istanbul: DEM Publishing.

[29] Ozdemir, S. (2017). Dini sosyal hizmet alanları (5. Basım) [Religious social work areas (5th Edition)]. Eds. Recai Dogan \& Remziye Ege. Din eğitimi el kitabı (içinde) [In: Religious education handbook]. 373-400. Ankara: Grafiker Publishing.

[30] Ozdemir, S. \& Arici, I. (2011). Alevi - Bektaşilerin din kültürü ve ahlak bilgisi dersine ilişkin görüşleri (Malatya örneği) [Alevi - Bektashis' views on religious culture and moral knowledge course (example of Malatya)]. Eds. Recep Kaymakcan, Mahmut Zengin ve Z. Seyma Arslan. Türkiye'de okullarda din ögrretimi (içinde) [In: Religious education in schools in Turkey]. 103-125. Istanbul: DEM Publishing.

[31] Ozdemir, S. (2017). Cezaevlerinde dini iletişim ve rehberlik (5. Basım) [Religious communication and guidance in prisons (5th Edition)]. Eds. Recai Dogan \& Remziye Ege. Din eğitimi el kitabı (içinde) [In: Religious education handbook]. 401-428. Ankara: Grafiker Publishing.

[32] Pak, S. Y. (2010). Cultural politics and vocational religious education: the case of Turkey. Comperative Education, 40: 3, 321-341. Retrieved April 16, 2020 from https://www.tandfonline. com/doi/full/10.1080/0305006042000274827?scroll=top\&ne edAccess=true.

[33] Subası, N. (2011). Müfredata dâhil olmak ya da Aleviliği okutmak [Inclusion in the curriculum or teaching Alevism]. Eds. Recep Kaymakcan, Mahmut Zengin ve Z. Seyma Arslan. Türkiye'de okullarda din öğretimi (içinde) [In: Religious education in schools in Turkey]. 55-63. Istanbul: DEM Publishing.

[34] Turan, I. (2018). Yaygın din eğitiminde Alevilik ve sorunları [Alevism and problems in non-formal religious education]. Ed. Mustafa Koylu. Türkiye'de din eğitimi ve sorunları (içinde) [In: Religious education and problems in Turkey]. 413-444. Istanbul: DEM Publishing.

[35] Uyanik, M. (2011). Okullarda isteğe bağlı din öğretimi tartı̧masına felsefi bir katkı [A philosophical contribution to the discussion of optional religious education in schools]. Eds. Recep Kaymakcan, Mahmut Zengin ve Z. Seyma Arslan. Türkiye'de okullarda din öğretimi (içinde) [In: Religious education in schools in Turkey]. 379- 399. Istanbul: DEM Publishing.

[36] Yildiz, I. (2011). Anayasal bir hak olarak isteğe bağlı din eğitimi [Optional religious education as a constitutional right]. Eds. Recep Kaymakcan, Mahmut Zengin ve Z. Seyma Arslan. Türkiye'de okullarda din öğretimi (içinde) [In: Religious education in schools in Turkey]. 411-426. Istanbul: DEM Publishing.

[37] Yilmaz, H. (2017). Cami eksenli din eğitimi (5. Basım) [Mosque-based religious education (5th Edition)]. Eds. Recai Dogan \& Remziye Ege. Din eğitimi el kitabı (içinde) [In: Religious education handbook]. p.113-135. Ankara: Grafiker Publishing.

[38] Yilmaz, Y. (2005). Türkiye'de din eğitimi [Religious education in Turkey]. Köprü Dergisi [Kopru Journal], Kış [Winter], Bilim-Din [Science-Religion], Vol. 89. Retrieved April 18, 2020 from https:// www.koprudergisi.com/index.asp?Bolum=EskiSayilar\&Goster=Yazi\&YaziNo $=659$ 
[39] Yorulmaz, B. (2018). Medyadaki dini faaliyetler ve sorunlar [Religious activities and issues in the media]. Ed. Mustafa Koylu. Türkiye'de Din Eğitimi ve Sorunlarn (içinde) [In: Religious education and problems in Turkey]. 445-480. Istanbul: DEM Publishing.

[40] Yükseköğretim Kurulu [YÖK] [Higher Education Council - HEC], (2020). YÖK Lisans Atlası [HEC Licence Atlas]. Retrieved April 17, 2020 from https://yokatlas.yok.gov.tr/lisans-anasayfa. php.

[41] Yuruk, T. (2017). İlk ve orta öğretimde din öğretimi (Din dersleri) (5. Basım) [Religious education in primary and secondary education (Religious lessons) (5th Edition)]. Eds. Recai Dogan \& Remziye Ege. Din eğitimi el kitabı (içinde) [In: Religious education handbook]. 113-135. Ankara: Grafiker Publishing.

[42] Zelyut, R. (1991). Öz kaynaklarnna göre Alevilik (6. Basım) [Alevism by own resources (6th Edition)]. Istanbul: Yön Publishing.

[43] Zengin, M. (2017). Cumhuriyet dönemi din dersi öğretim programlarnnda ve ders kitaplarnda dinler, inançlar ve islam düşüncesinde yorumlar [Religions, beliefs and comments in ıslamic thought in the republican era religious lesson curriculum and textbooks]. Istanbul: DEM Publishing.

[44] Zengin, Z. S. (2011). Osmanlıdan cumhuriyete mekteplerde din dersleri ve programlardaki gelişmeler [Religious lessons in schools from ottoman to republic and developments in programs]. Eds. Recep Kaymakcan, Mahmut Zengin ve Z. Seyma Arslan. Türkiye'de okullarda din ögretimi (içinde) [In: Religious education in schools in Turkey]. 153-174. Istanbul: DEM Publishing. 